\title{
Investigating needle stick injuries: Incidence, knowledge and perception among South Jordanian nursing students
}

\author{
Hani A. Nawafleh*1, Shalabia El Abozead ${ }^{2}$, Muwafaq M. Al Momani ${ }^{1}$, Heyam Aaraj ${ }^{1}$ \\ ${ }^{1}$ Princess Aisha Bint Al Hussein College of Nursing and Health Sciences, Al Hussein Bin Talal University, Ma'an, Jordan \\ ${ }^{2}$ Faculty of Nursing, Assiut University, Assiut, Egypt
}

Received: August 20, 2017

DOI: $10.5430 /$ jnep.v8n4p59
Accepted: November 27, $2017 \quad$ Online Published: November 29, 2017

URL: https://doi.org/10.5430/jnep.v8n4p59

\begin{abstract}
Needle stick injury (NSI) is one of the major causes of blood borne infections in the present day healthcare system. Among healthcare professionals, nursing students will most likely be exposed to this dilemma. Interventions like institutionalizing educational programs to produce awareness and knowledge among nurses can depict positive outcomes in changing perceptions toward safety measures. This study aimed to investigate the incidence, perspectives, views, perceptions, and knowledge of NSIs among nursing students studying at Al-Hussein Bin Talal University. The sample population consisted of all undergraduate nursing students from second to fourth academic levels at the university who consented to participate in this study. The mode of data collection utilized a self-structured questionnaire apportioned into four parts. The first portion of the questionnaire presented the socio-demographic details of the respondents. The second part of the questionnaire demonstrated questions about needle stick incidences at the clinical units of the participants; frequency of occurrences (i.e., number, nature, and rationale); place of occurrence; and, whether the event was reported to higher authorities. The third part of the questionnaire entailed queries associated with the knowledge of the students with respect to needle stick injury. The last part focused on the student's knowledge and perception on the risks associated to needle sticks injuries and the relative precautions to prevent such. The results showed that most of the students had positive perception of NSIs; while two thirds of the student nurses experienced NSI with increasing number of injured nurses occurring among second year students. This is due to the lack of knowledge regarding universal precaution guidelines and acupuncture safety device. Nursing students are at risks of getting infection. Proper steps are needed to promote awareness of NSI as well as the dangers and prevention from such events.
\end{abstract}

Key Words: Infection, Incidence, Needle stick, Nursing students, Jordan

\section{INTRODUCTION}

Leliopoulou et al. (1999) and Angadi et al. (2016) explained that blood borne infections are the most important occupational risk factors for healthcare professionals. ${ }^{[1,2]}$ Human Immunodeficiency Virus (HIV), Cytomegalovirus and Hepatitis B \& C have been identified as occupational health infections of significant consideration. Angrup et al. (2013) stated that among the 35 million healthcare workers (HCWs) worldwide, 3 million of which came across percutaneous exposures to blood pathogens yearly. ${ }^{[3]}$ This signified that almost 2 million HCWs are exposed to hepatitis B virus (HBV); 0.9 million to hepatitis C virus (HCV); and 170,000

\footnotetext{
* Correspondence: Hani A. Nawafleh; Email: hnawafleh@ahu.edu.jo; Address: Princess Aisha Bint Al Hussein College of Nursing and Health Sciences, Al Hussein Bin Talal University, Ma'an, Jordan.
} 
to Human Immunodeficiency Virus (HIV). According to Papastergiou et al. (2015), more than 350 million are chronically infected with HBV around the world, especially in areas of low endemicity to 8 percent in high endemic areas with intense endemic foci in the Western Pacific Regions and Southeast Asia. ${ }^{[4]}$

Hassan and Wahsheh (2009) explained that there is a subjective requirement to provide educational and training courses to healthcare workers who have experience of more than 2 years in the medical and nursing fields. ${ }^{[5]}$ Similarly, NSIs possess a continuous risk of blood borne infections and is the source of occupational hazard for all the workers involved in the clinical field. ${ }^{[2,6,7]}$ A study by Khader et al. (2009) demonstrated that among the dentists in Jordan, NSIs were reportedly associated with age and number of patients treated per day. ${ }^{[8]}$ It was found that 77.9 percent of dentists who got injured did not report the incidence. On the contrary, Jahangiri et al. (2016) depicted that there was a subjective increase in the prevalence of NSIs among nursing students. ${ }^{[9]}$

Nurses are an integral part of the healthcare team working in clinical units. They face many occupational health hazards, such as ergonomic risks, chemical exposures, exposure to blood and body fluids, and occupational stress. Dement et al. (2004) explained that exposure to human blood and body fluids pose as a risk to blood borne infections. ${ }^{[10]}$ Hence, the nursing students need to be cautious in identifying the risks while working in a clinical setting. In this regard, the lack of experience and the anxiety related to the first encounter with the clinical techniques may lead to potential risks and accidents. $^{[11]}$ It is true that nursing students are at higher risk for NSIs and sharps injuries (SIs) as compared to other healthcare team members. However, there are informational gap among existing research materials on NSIs and SIs in relation to varying level of nursing education. ${ }^{[12]}$

Nursing students build up their aptitudes by performing methods in which they have to handle cutting and puncturing objects with conceivable coincidental contact with body liquids. Some reviews accounted that healthcare workers, especially, nursing students have higher danger of NSIs as compared to graduates who are already experts in the field. ${ }^{[13]}$ More noteworthy is the susceptibility of nursing students, which may be due to lack of experience, inadequate ability and lack of proper information on how to handle certain instruments; nervousness; tiredness; absence of instructional exercises and trainings; carelessness lack of care for oneself and for others in the vicinity. ${ }^{[14]}$

Therefore, the educators and managers in the nursing units are required to regularly evaluate the realities and practices in the clinical units. Having regular assessment and evaluation of the events and practices may not only help in the ramifications of the teaching approaches but may also instigate moral implications. Jordanian nursing instructors provide practical tests to acquaint students with distinctive modalities that adequately interpret hypothetical infection and contamination control information into safe practices. ${ }^{[15]}$ Additionally, in the nursing practice, it is essential for all nurses to study modified educational materials within the context of the nursing curriculum context for them to inculcate qualitative infection control guidelines and improve their compliance. ${ }^{[16]}$ Hence, there is a substantive need for better education of the students in the nursing clinical field and more effective supervision in relation to NSIs. ${ }^{[17]}$

\section{Significance of the study}

According to a nationwide multi-centre study conducted in Jordan among nursing students, which assessed their extent of knowledge on NSIs rates and exposure to blood borne infectious vectors; nursing students were found to be deficit in handling such trivial clinical issues on their own. Hence, the non-compliance of nursing students with infection control precautions have adverse outcomes not only on patients, but also on the nursing students themselves. Since there is a large gap in the existing literature on exposure of nursing students to NSIs, the level and depth of infection control knowledge and compliance among Jordanian nursing students need to be further investigated. ${ }^{[18]}$ The purpose of this cross-sectional survey is to detect rates of needle stick injury among South Jordanian nursing students and to identify their level of knowledge and perception of needle stick injury.

\section{SUBJECT AND METHODS}

A self-structured questionnaire composed of four parts was used: The first part presented socio-demographic questions about the respondent. The second part included questions about NSI events during clinical practice, specifically, frequency of NSIs (including number, nature, and reason); the body parts where NSIs occurred; and whether the event was reported. The third part covered questions related to the student's knowledge of needle stick injury. While, the fourth part pertained to the student's perception on risk of NSIs and universal precaution.

Pilot study was conducted among 10 percent of the nursing students who consented as respondents to the questionnaire. This pilot run aimed to test the feasibility and comprehensiveness of the survey design. After which, fundamental changes were done on the study design and the implementation process based on expert opinions on the initial results of the survey. 


\subsection{Research objectives}

(1) To describe the incidence rate of needle stick injuries among nursing students in Jordan.

(2) To identify the level of knowledge regarding needle stick injury among Jordanian nursing students.

(3) To assess nurses' perception on the potential risk of needle sticks injuries.

(4) To examine the extent to which nursing students in Jordan adhere and comply with universal precautions of managing needle stick.

\subsection{Design}

This research project utilized a cross-sectional survey designed in view of a self-administered questionnaire directed among the undergraduate nursing students (from second to final year of nursing education). A self-explanatory configuration was utilized to investigate and evaluate the circumstantial conditions to establish the incidence rate, learning curve, and perception analysis of needle stick injuries among nursing students studying at Al-Hussein University.

\subsection{Setting}

The study was conducted at the Princess Aisha Bint AlHussein Faculty of Nursing and Health Sciences of AlHussein Bin Talal University in Jordan.

\subsection{Sample}

The total sample consisted of 162 undergraduate nursing students belonging to the second to fourth academic years at the university, 38 of whom were males and 124 females, who consented to participate in the study. Table 1 shows that the majority of student nurses were female.

\subsection{Data collection procedure}

Ethical approval was sought from the Al-Hussein Bin Talal University Research Ethics Committee. Permission to implement the research project was granted by the Dean of the Faculty of Nursing and Health Sciences, as well as, the teaching staff. Prior to the distribution of questionnaires to the respondents, they were oriented about the study process and the most proficient method to fill out the questionnaire with utmost honesty. The research analysts dispensed the questionnaire during the start of their classes.

\subsection{Data analysis}

Survey data were analyzed using the Statistical Package for Social Sciences (Version 20.0, SPSS, Inc) software. Further, a descriptive statistic was used and the inferences were expressed as means $\pm \mathrm{SD}$ (standard deviation). Frequency, percentage, and parametric variables were also assessed and determined using students' $t$ test, while chi-squared analyses were conducted for non-parametric variables. Moreover, all reported $p$ values were made on the basis of 2-sided tests and it was compared to a significance level of 5 percent; while differences were considered statistically significant at $p<$ .05 .

Table 1. Demographic characteristics of study sample

\begin{tabular}{|c|c|c|c|c|c|c|c|c|c|c|}
\hline \multirow{3}{*}{ Sample Population } & \multicolumn{8}{|c|}{ Academic Level of Nursing Students } & \multirow{3}{*}{$\begin{array}{l}\text { Mean } \\
\text { scores }\end{array}$} & \multirow{3}{*}{$p$} \\
\hline & \multicolumn{2}{|l|}{$2^{\text {nd }}$} & \multicolumn{2}{|l|}{$3^{\text {rd }}$} & \multicolumn{2}{|l|}{$4^{\text {th }}$} & \multicolumn{2}{|c|}{ Total } & & \\
\hline & n & $\%$ & $\mathbf{n}$ & $\%$ & $\mathbf{n}$ & $\%$ & $\mathbf{n}$ & $\%$ & & \\
\hline Male & 14 & 37 & 8 & 21 & 16 & 42 & 38 & 23 & \multirow{2}{*}{1.77} & \multirow{2}{*}{.823} \\
\hline Female & 39 & 32 & 21 & 23 & 56 & 45 & 124 & 77 & & \\
\hline Total & 53 & 33 & 37 & 23 & 72 & 44 & 162 & 100 & & \\
\hline
\end{tabular}

\section{Results}

The results showed that two thirds of the student nurses experienced NSI with increased number of injured nurses during their secondary year of study. This is due to the lack of knowledge regarding universal precaution guidelines and needle safety device.

\subsection{Incidence of needle stick injuries: Frequency, cir- cumstances and practices}

Table 2 illustrates that two thirds of the student nurses experienced NSI with increased number of injury among student nurses at the secondary level since almost half of them had been injured at one time or the other. Main reason for most injuries were due to injection, for which majority of the students agree to recap the needle after use. Furthermore, around half of the students didn't tell anyone about the injuries nor undergone blood test after the injury. Most of the NSI cases occurred in the emergency units and the medical surgical units.

\subsection{Students' knowledge concerning NSI}

Table 3 shows the students' knowledge about the universal precaution guidelines: $57 \%$ of the respondents answered yes, mostly from the fourth year nursing students. 
Table 2. Correlation of incidences and circumstances of NSI by academic year level

\begin{tabular}{|c|c|c|c|c|c|c|c|c|c|c|}
\hline \multirow{2}{*}{ Variables } & \multirow{2}{*}{ Study year } & \multicolumn{2}{|l|}{$2^{\text {nd }}$} & \multicolumn{2}{|l|}{$3^{\text {rd }}$} & \multicolumn{2}{|l|}{$4^{\text {th }}$} & \multicolumn{2}{|c|}{ Total } & \multirow{2}{*}{$p$} \\
\hline & & $\mathbf{n}$ & $\%$ & n & $\%$ & $\mathbf{n}$ & $\%$ & $\mathbf{n}$ & $\%$ & \\
\hline \multirow{3}{*}{$\begin{array}{l}\text { Did you } \\
\text { experience NSI? }\end{array}$} & Yes & 31 & 41 & 14 & 19 & 30 & 40 & 75 & 46 & \multirow{3}{*}{.163} \\
\hline & No & 23 & 26 & 23 & 26 & 41 & 48 & 87 & 54 & \\
\hline & Mean score & 0.57 & & 0.38 & & 0.43 & & 0.46 & & \\
\hline \multirow{5}{*}{$\begin{array}{l}\text { How many } \\
\text { times had you } \\
\text { experienced } \\
\text { NSIs? }\end{array}$} & Once & 19 & 64 & 4 & 28.5 & 20 & 65 & 43 & 57 & \multirow{5}{*}{.001} \\
\hline & Twice & 9 & 30 & 1 & 7 & 7 & 23 & 17 & 23 & \\
\hline & Thrice & 1 & 3 & 4 & 28.5 & 2 & 6 & 7 & 9 & \\
\hline & Four times & 0 & 0 & 0 & 0 & 2 & 6 & 2 & 3 & \\
\hline & Five+ times & 1 & 3 & 5 & 36 & 0 & 0 & 6 & 8 & \\
\hline \multirow{4}{*}{$\begin{array}{l}\text { In which study } \\
\text { level did NSI } \\
\text { occurred most }\end{array}$} & Second Year & 28 & 94 & 14 & 100 & 24 & 77 & 66 & 88 & \multirow{4}{*}{.053} \\
\hline & Third Year & 0 & 0 & 0 & 0 & 0 & 0 & 0 & 0 & \\
\hline & Fourth Year & 1 & 3 & 0 & 0 & 7 & 23 & 8 & 11 & \\
\hline & All Levels & 1 & 3 & 0 & 0 & 0 & 0 & 1 & 1 & \\
\hline \multirow{7}{*}{$\begin{array}{l}\text { Reason/s for } \\
\text { NSI }\end{array}$} & Workload & 4 & 13 & 3 & 22 & 17 & 55 & 24 & 32 & \multirow{7}{*}{.020} \\
\hline & Recapping & 3 & 10 & 2 & 14 & 0 & 0 & 5 & 7 & \\
\hline & Quickness & 5 & 17 & 1 & 7 & 0 & 0 & 6 & 8 & \\
\hline & Patient not co-operative & 1 & 3 & 1 & 7 & 0 & 0 & 2 & 2 & \\
\hline & Preparation of medications & 2 & 7 & 0 & 0 & 3 & 10 & 5 & 7 & \\
\hline & At injection & 14 & 47 & 43 & 43 & 8 & 25 & 28 & 37 & \\
\hline & Others & 1 & 3 & 1 & 7 & 3 & 10 & 5 & 7 & \\
\hline \multirow{3}{*}{$\begin{array}{l}\text { Did you recap } \\
\text { the needle? }\end{array}$} & Yes & 28 & 93 & 14 & 100 & 26 & 84 & 68 & 91 & \multirow{3}{*}{.184} \\
\hline & No & 2 & 7 & 0 & 0 & 5 & 16 & 7 & 9 & \\
\hline & Mean score & 0.07 & & 0 & & 0.16 & & 0.09 & & \\
\hline \multirow{3}{*}{$\begin{array}{l}\text { Did you report } \\
\text { the NSI event? }\end{array}$} & Yes & 11 & 37 & 8 & 57 & 24 & 77 & 43 & 57 & \\
\hline & No & 19 & 63 & 6 & 6 & 7 & 23 & 32 & 43 & .006 \\
\hline & Mean score & 0.37 & & 0.57 & & 0.77 & & 0.57 & & \\
\hline & Teacher & 5 & 31 & 3 & 30 & 2 & 7 & 10 & 19 & \\
\hline To whom did & Friends & 7 & 44 & 2 & 20 & 11 & 41 & 20 & 38 & \\
\hline you report? & Head Nurse & 0 & 0 & 2 & 20 & 12 & 45 & 14 & 26 & \\
\hline & Nurse & 4 & 25 & 3 & 30 & 2 & 7 & 9 & 17 & \\
\hline & Did not know how to report & 0 & 0 & 5 & 63 & 4 & 33 & 9 & 24 & \\
\hline & $\begin{array}{l}\text { Too embarrassed and were worried about } \\
\text { getting in trouble }\end{array}$ & 6 & 33 & 1 & 12 & 3 & 25 & 10 & 26 & \\
\hline $\begin{array}{l}\text { Reasons why } \\
\text { you didn't }\end{array}$ & $\begin{array}{l}\text { Too busy' and did not want to be seen as having } \\
\text { poor clinical skills }\end{array}$ & 6 & 33 & 0 & 0 & 5 & 42 & 11 & 29 & 20? \\
\hline $\begin{array}{l}\text { report the NSI } \\
\text { event? }\end{array}$ & $\begin{array}{l}\text { Worried that reporting the injury would affect } \\
\text { their grades }\end{array}$ & 0 & 0 & 2 & 25 & 0 & 0 & 2 & 5 & .002 \\
\hline & $\begin{array}{l}\text { Lack of awareness of the risks associated with } \\
\text { contaminated needles or sharps }\end{array}$ & 1 & 6 & 0 & 0 & 0 & 0 & 1 & 3 & \\
\hline & Others & 5 & 28 & 0 & 0 & 0 & 0 & 5 & 13 & \\
\hline & Put pressure on the site & 3 & 10 & 2 & 2 & 11 & 36 & 16 & 21 & \\
\hline & Squeeze the puncture site and then wash it & 4 & 13 & 4 & 4 & 15 & 48 & 23 & 31 & \\
\hline What did you do & Wash with soap and water & 10 & 33 & 0 & 0 & 0 & 0 & 10 & 13 & 001 \\
\hline event? & Apply antiseptic solution & 8 & 27 & 0 & 0 & 0 & 0 & 8 & 11) & \\
\hline & Washing the site with running water & 5 & 17 & 1 & 7 & 0 & 0 & 6 & 8 & \\
\hline & Nothing & 0 & 0 & 7 & 50 & 5 & 16 & 12 & 16 & \\
\hline Have you done & Yes & 2 & 7 & 1 & 7 & 10 & 32 & 13 & 17 & \\
\hline any blood test & No & 28 & 93 & 13 & 93 & 21 & 68 & 62 & 83 & .0016 \\
\hline after the injury? & Mean score & 0.7 & & 0.7 & & 0.32 & & 0.17 & & \\
\hline & Medical-surgical & 3 & 10 & 2 & 14 & 10 & 32 & 15 & 20 & \\
\hline In which & ICU & 9 & 30 & 0 & 0 & 1 & 3 & 10 & 13 & \\
\hline medical unit did & Laboratory & 0 & 0 & 5 & 36 & 0 & 0 & 5 & 7 & .001 \\
\hline occurred most? & Emergency & 14 & 47 & 5 & 36 & 15 & 49 & 34 & 45 & \\
\hline & Other & 4 & 13 & 2 & 14 & 5 & 16 & 11 & 15 & \\
\hline
\end{tabular}


Table 3. Correlation of students knowledge concerning NSI

\begin{tabular}{|c|c|c|c|c|c|c|c|c|c|c|}
\hline \multirow{2}{*}{ Variable } & \multirow[t]{2}{*}{ tudy years } & \multicolumn{2}{|l|}{$2^{\text {nd }}$} & \multicolumn{2}{|l|}{$3^{\text {rd }}$} & \multicolumn{2}{|l|}{$4^{\text {th }}$} & \multicolumn{2}{|c|}{ Total } & \multirow{2}{*}{$p$} \\
\hline & & $\mathbf{n}$ & $\%$ & $\mathbf{n}$ & $\%$ & $\mathbf{n}$ & $\%$ & $\mathbf{n}$ & $\%$ & \\
\hline \multirow{3}{*}{$\begin{array}{l}\text { Do you know about universal } \\
\text { precaution guidelines? }\end{array}$} & Yes & 27 & 51 & 20 & 54 & 46 & 64 & 93 & 57 & \\
\hline & No & 26 & 49 & 17 & 46 & 26 & 35 & 69 & 43 & .315 \\
\hline & M. score & 0.51 & & 0.54 & & 0.6 & & 0.57 & & \\
\hline \multirow{3}{*}{$\begin{array}{l}\text { Do you know about needles safety } \\
\text { device? }\end{array}$} & Yes & 12 & 23 & 15 & 41 & 25 & 35 & 52 & 32 & \\
\hline & No & 41 & 77 & 22 & 59 & 47 & 65 & 110 & 68 & .164 \\
\hline & M. score & 0.23 & & 0.41 & & 0.35 & & 0.32 & & \\
\hline \multirow{3}{*}{$\begin{array}{l}\text { Can Hepatitis B be transmitted by } \\
\text { NSI? }\end{array}$} & Yes & 53 & 100 & 36 & 97 & 58 & 81 & 147 & 91 & \\
\hline & No & 0 & 0 & 1 & 3 & 14 & 19 & 15 & 9 & .001 \\
\hline & M. score & 1.0 & & 0.97 & & 0.81 & & 0.93 & & \\
\hline \multirow{3}{*}{$\begin{array}{l}\text { Can Hepatitis C be transmitted by } \\
\text { NSI? }\end{array}$} & Yes & 40 & 75 & 32 & 86 & 63 & 88 & 135 & 83 & \\
\hline & No & 13 & 25 & 5 & 14 & 9 & 12 & 27 & 17 & .172 \\
\hline & M. score & 0.25 & & 0.14 & & 0.12 & & 0.17 & & \\
\hline \multirow{3}{*}{$\begin{array}{l}\text { Can HIV/AIDS be transmitted by } \\
\text { NSI? }\end{array}$} & Yes & 44 & 83 & 36 & 97 & 62 & 86 & 142 & 88 & \\
\hline & No & 9 & 17 & 1 & 3 & 10 & 14 & 20 & 12 & .111 \\
\hline & M. score & 0.83 & & 0.97 & & $0.8 €$ & & 0.89 & & \\
\hline \multirow{3}{*}{$\begin{array}{l}\text { Do you need to wear gloves during } \\
\text { phlebotomy? }\end{array}$} & Yes & 40 & 75 & 25 & 25 & 64 & 89 & 129 & 80 & \\
\hline & No & 13 & 25 & 12 & 32 & 8 & 11 & 33 & 20 & .021 \\
\hline & M. score & 0.75 & & 0.68 & & $0.8 s$ & & 0.80 & & \\
\hline \multirow{3}{*}{$\begin{array}{l}\text { Do you use gloves during } \\
\text { phlebotomy? }\end{array}$} & Yes & 34 & 64 & 15 & 41 & 45 & 62 & 94 & 58 & \\
\hline & No & 19 & 36 & 22 & 59 & 27 & 38 & 68 & 42 & .048 \\
\hline & M. score & 0.64 & & 0.41 & & 0.62 & & 0.58 & & \\
\hline \multirow{3}{*}{$\begin{array}{l}\text { Do you wear gloves when } \\
\text { withdrawing a needle or cannula } \\
\text { from a patient? }\end{array}$} & Yes & 27 & 51 & 15 & 41 & 50 & 69 & 92 & 57 & \\
\hline & No & 26 & 49 & 22 & 59 & 22 & 31 & 70 & 43 & .009 \\
\hline & M. score & 0.51 & & 0.41 & & 0.65 & & 0.57 & & \\
\hline \multirow{3}{*}{ Should needles be bent after use? } & Yes & 13 & 25 & 11 & 30 & 15 & 21 & 39 & 24 & \\
\hline & No & 40 & 75 & 26 & 70 & 57 & 79 & 123 & 76 & .587 \\
\hline & M. score & 0.75 & & 0.70 & & $0.7 \mathrm{c}$ & & 0.76 & & \\
\hline \multirow{3}{*}{ Do you recap needles after use? } & Yes & 46 & 87 & 33 & 89 & 60 & 83 & 139 & 86 & \\
\hline & No & 7 & 13 & 4 & 11 & 12 & 17 & 23 & 14 & .687 \\
\hline & M. score & 0.13 & & 0.11 & & 0.17 & & 0.14 & & \\
\hline \multirow{3}{*}{$\begin{array}{l}\text { Do you disassemble used needle } \\
\text { with your hands? }\end{array}$} & Yes & 33 & 62 & 13 & 35 & 17 & 24 & 63 & 39 & \\
\hline & No & 20 & 38 & 24 & 65 & 55 & 76 & 99 & 61 & .001 \\
\hline & M. score & 0.38 & & 0.65 & & $0.7 €$ & & 0.61 & & \\
\hline \multirow{3}{*}{$\begin{array}{l}\text { Do you wear gloves when } \\
\text { disposing contaminated needles? }\end{array}$} & Yes & 40 & 75 & 18 & 49 & 51 & 71 & 109 & 67 & \\
\hline & No & 13 & 25 & 19 & 51 & 21 & 29 & 53 & 33 & .020 \\
\hline & M. score & 0.75 & & 45 & & 0.71 & & 0.67 & & \\
\hline \multirow{3}{*}{$\begin{array}{l}\text { Do you separate the needle from } \\
\text { the syringe prior to disposal? }\end{array}$} & Yes & 34 & 64 & 31 & 84 & 52 & 72 & 117 & 72 & \\
\hline & No & 19 & 36 & 6 & 16 & 20 & 28 & 45 & 28 & .123 \\
\hline & M. score & 0.36 & & 0.16 & & 0.28 & & 0.28 & & \\
\hline & Yes & 48 & 91 & 31 & 84 & 48 & 67 & 127 & 78 & \\
\hline Do you throw used needies into & No & 5 & 9 & 6 & 16 & 24 & 33 & 35 & 22 & .004 \\
\hline & M. score & 0.91 & & 0.84 & & 0.67 & & 0.78 & & \\
\hline & Yes & 53 & 100 & 31 & 84 & 67 & 93 & 151 & 93 & \\
\hline Do NSI need to be reported? & No & 0 & 0 & 6 & 16 & 5 & 7 & 11 & 7 & .011 \\
\hline & M. score & 0.100 & & 0.84 & & 0.93 & & 0.93 & & \\
\hline
\end{tabular}

When the respondents were asked about the needle safety devices, only $32 \%$ of them knew about the needle's security apparatus. This low index indicated ignorance of a large portion of the participants about this safety device. It was noted that the third year students had the best batting percentage. Referring to the possibility of HBV that travels through the needle stick, $91 \%$ of the respondents replied that this virus is transmitted through needle stick indicating that a large percentage of nursing students accept this fact. The highest percentage were among the second year level students with statistical mean significance of 1.0. 
With regards HIV transmission through needle stick, $88 \%$ of the respondents answered positively. The participants response about wearing gloves during phlebotomy procedure was highly positive at $80 \%$. It was also noted that the highest percentage was among the fourth year students and the least was among the third year students.

Generally, $76 \%$ of the nursing students who answered negatively were aware that needles should not be bent after use and $78 \%$ of them throw the needle immediately to the sharps bin. However, $86 \%$ of the nursing students tended to recap the needle after use and $72 \%$ separated the needle from the syringe before disposal. Most of the respondents (67\%) wear gloves when disposing contaminated needles, $75 \%$ of whom are second year level nursing students. Similarly, hundred percent of the second year level students had the perfect percentage from the $93 \%$ of the respondents who were aware that NSI incidences should be reported immediately.

\subsection{Perception on risks of NSIs}

Table 4 shows that $82 \%$ of the respondents in all study years agreed that all students are prone to NSI, the highest percentage $(93 \%)$ were among the third year students. Similarly, $73 \%$ of all respondents opined that increased workload may lead to needle prick. Most respondents (64\%) disagreed that injured students infected with HIV must be separated from the college, especially the fourth year level students (71\%). They reasoned out that this matter should be decided upon by the university.

Observably, 88\% of all students agree that poor handling of sharp materials lead to infection. Second year level students perfectly agree on this a hundred percent. The students' response in dealing with needles without wearing gloves was negative at $59 \%$ especially among fourth year students of whom $64 \%$ disagreed. Similarly, most of the students (64\%) disagreed to the statement that reporting NSI is not useful. These disagreements indicated that a considerable proportion of the nursing students understand the dangers of not using protective gloves in handling needles and non-reporting of NSI.

Most of the students agreed at $96 \%$ that all students must be immunized with Hepatitis B vaccine; mostly second year level students are agreeable to this statement at $98 \%$. Health education on the universal precaution against NSI was highly approved by $89 \%$ of all students respondents, especially second year students. Great majority of the respondents at $98 \%$ agreed that safe way of handling needle will help reduce the incidence of NSIs. The fourth year students perfectly agreed to this statement a hundred percent, followed by the second year students at $98 \%$ and the third year students at
$95 \%$, respectively.

Table 5 shows that there were statistical significance of positive and negative attitude between perception on risk of NSI and universal precaution for most of the questionnaire items provided in Table 4.

\section{Discussion}

Needle stick and sharp injuries are the most significant hazards that threaten the safety of nurses and other healthcare workers inside the medical centers since this is the most common cause by which blood borne pathogens can be transmitted between patients, students, and other healthcare workers. This study revealed that about two thirds of the student nurses in Jordan had experienced NSIs, with increased number of incidences among students in the second year of nursing education. Further, around half of the students did not tell anyone about the injuries nor have done any blood test after the NSI incidence. Most of the NSI cases occurred in the emergency units and the medical surgical units. Omer et al. (2015) showed that the NSIs represent the most common mode of exposure in 189 (75.9\%) healthcare personnel; ${ }^{[19]}$ while Salmanzadeh et al. (2015) showed that the highest frequency of NSIs were observed among medical staff (79.7\%). ${ }^{[20]}$

A study by Askarian and Malekmakan (2006) reported that $71.1 \%(489 / 688)$ of the students experienced NSIs which usually occurred in the patient rooms (43.6\%); while $82 \%$ (401/489) of NSIs were not reported. ${ }^{[21]}$ Similarly, a study by Shiao et al. (2002), revealed that the incidences of NSIs during the internship years accounted for $61.9 \%$ (438/708) of students, $14.2 \%$ (62/438) of whom made a formal report, and the dominant part $(70.1 \%)$ have not reported NSI incidences in the patient's room. ${ }^{[22]}$ Moreover, the hollow-bore needles added to half $(219 / 438)$ of the NSIs of which $86.8 \%$ were syringe needles. Simply over half $(53.2 \%)$ of those things required in NSIs had been utilized on patients, and therefore, reported NSIs as well as non-reporting of NSIs were very common among nursing students. In a country where there is lack of standard reporting conventions and underreporting is high as $33 \%$, hence, the proportion of people being influenced by this negative practice is much higher than what is actually being reported. ${ }^{[23]}$ Hence, the recurrence of NSIs among nursing students and healthcare workers is high, while incidence reporting is low. What should be further examined are the mediations, for example, administration and preparation of disease control measures, including institutionalized treatment and follow-up are vital. ${ }^{[24]}$

The introduction of the new sharp-safe needles diminished NSI incidence by $26 \%$ compared with the earlier years. ${ }^{[25]}$ More serious training projects ought to guide students to 
expand their familiarity and compliance with Universal Pre- vided. Yang et al. (2007) specified that after instructive cautions (UP) before getting involved in their clinical and arbitration, the frequency of NSIs/SIs diminished altogether nursing work practices. Instructions about the transmission from 50.5\% pre-test to $25.2 \%$ post-test, and the report rate of blood borne diseases, standard safety measures, and ex- expanded from $37.0 \%$ to $55.6 \%$, separately. ${ }^{[13]}$ panding accessibility of insurance procedures must be pro-

Table 4. Perception on risk of needle sticks injuries and universal precaution among students

\begin{tabular}{|c|c|c|c|c|c|c|c|c|c|c|}
\hline \multirow[b]{2}{*}{ Variable } & \multirow[t]{2}{*}{ tudy years } & \multicolumn{2}{|l|}{$2^{\text {nd }}$} & \multicolumn{2}{|l|}{$3^{\text {rd }}$} & \multicolumn{2}{|l|}{$4^{\text {th }}$} & \multicolumn{2}{|c|}{ Total } & \multirow{2}{*}{$p$} \\
\hline & & $\mathbf{n}$ & $\%$ & $\mathbf{n}$ & $\%$ & $\mathbf{n}$ & $\%$ & $\mathbf{n}$ & $\%$ & \\
\hline \multirow{4}{*}{$\begin{array}{l}\text { Nursing students are prone to } \\
\text { NSI }\end{array}$} & Agree & 47 & 89 & 36 & 93 & 50 & 70 & 133 & 182 & \multirow{4}{*}{.004} \\
\hline & Disagree & 6 & 11 & 1 & 3 & 21 & 29 & 28 & 17 & \\
\hline & Don’t know & 0 & 0 & 0 & 0 & 1 & 1 & 1 & 1 & \\
\hline & M. score & 1.77 & & 1.94 & & 1.40 & & 1.65 & & \\
\hline \multirow{4}{*}{$\begin{array}{l}\text { Increase workload can lead to } \\
\text { NSI }\end{array}$} & Agree & 38 & 72 & 30 & 81 & 50 & 69 & 118 & 73 & \multirow{4}{*}{.004} \\
\hline & Disagree & 10 & 19 & 6 & 16 & 17 & 24 & 33 & 20 & \\
\hline & Don't know & 5 & 9 & 1 & 3 & 5 & 7 & 11 & 7 & \\
\hline & M. score & 1.53 & & 1.65 & & 1.46 & & 1.52 & & \\
\hline \multirow{4}{*}{$\begin{array}{l}\text { Students infected with HIV } \\
\text { should resign from their school }\end{array}$} & Agree & 17 & 32 & 11 & 30 & 7 & 10 & 35 & 22 & \multirow{4}{*}{.001} \\
\hline & Disagree & 35 & 66 & 18 & 48 & 51 & 71 & 104 & 64 & \\
\hline & Don't know & 1 & 2 & 8 & 22 & 14 & 19 & 23 & 14 & \\
\hline & M. score & 1.34 & & 1.19 & & 1.61 & & 1.43 & & \\
\hline \multirow{4}{*}{$\begin{array}{l}\text { Improper handling of the sharp } \\
\text { objects can lead to infection }\end{array}$} & Agree & 53 & 100 & 29 & 78 & 61 & 85 & 143 & 88 & \multirow{4}{*}{.015} \\
\hline & Disagree & 0 & 0 & 5 & 14 & 5 & 7 & 10 & 6 & \\
\hline & Don't know & 0 & 0 & 3 & 8 & 6 & 8 & 9 & 6 & \\
\hline & M. score & 2 & & 1.64 & & 1.78 & & 1.82 & & \\
\hline \multirow{4}{*}{$\begin{array}{l}\text { Although there is risk of } \\
\text { infection, confidence and } \\
\text { skillfulness can prevent NSI }\end{array}$} & Agree & 40 & 75 & 32 & 86 & 47 & 65 & 119 & 74 & \multirow{4}{*}{.002} \\
\hline & Disagree & 12 & 23 & 4 & 11 & 10 & 14 & 26 & 16 & \\
\hline & Don’t know & 1 & 2 & 3 & 3 & 15 & 21 & 17 & 10 & \\
\hline & M. score & 1.53 & & 1.76 & & 1.51 & & 1.57 & & \\
\hline \multirow{4}{*}{$\begin{array}{l}\text { Unavailability of protective } \\
\text { equipment can predispose a } \\
\text { person to get NSI }\end{array}$} & Agree & 37 & 70 & 22 & 60 & 53 & 74 & 112 & 69 & \multirow{4}{*}{.622} \\
\hline & Disagree & 13 & 25 & 12 & 32 & 14 & 19 & 39 & 39 & \\
\hline & Don’t know & 3 & 5 & 3 & 8 & 5 & 7 & 11 & 11 & \\
\hline & M. score & 1.45 & & 1.27 & & 1.54 & & 1.45 & & \\
\hline \multirow{4}{*}{$\begin{array}{l}\text { Handling needle without } \\
\text { wearing gloves is easier and } \\
\text { safer than wearing gloves }\end{array}$} & Agree & 19 & 36 & 11 & 30 & 16 & 22 & 46 & 29 & \multirow{4}{*}{.549} \\
\hline & Disagree & 29 & 55 & 21 & 56 & 46 & 64 & 96 & 59 & \\
\hline & Don't know & 5 & 9 & 5 & 14 & 10 & 14 & 20 & 1 & \\
\hline & M. score & 1.19 & & 1.27 & & 1.42 & & 1.31 & & \\
\hline & Agree & 8 & 15 & 14 & 38 & 13 & 18 & 35 & 21 & \\
\hline Reporting after the NSI event is & Disagree & 30 & 57 & 20 & 54 & 53 & 74 & 103 & 64 & $0 \cap 1$ \\
\hline not useful & Don’t know & 15 & 28 & 3 & 8 & 6 & 8 & 24 & 15 & .001 \\
\hline & M. score & 1.41 & & 1.16 & & 1.56 & & 1.42 & & \\
\hline & Agree & 52 & 98 & 36 & 97 & 67 & 93 & 155 & 96 & \\
\hline Every student should be & Disagree & 1 & 2 & 1 & 3 & 0 & 0 & 2 & 1 & .089 \\
\hline immunızed with Hepatitıs B & Don’t know & 0 & 0 & 0 & 0 & 5 & 7 & 5 & 3 & \\
\hline & M. score & 1.96 & & 1.95 & & 1.93 & & 1.94 & & \\
\hline Health education on universal & Agree & 52 & 98 & 33 & 89 & 60 & 84 & 145 & 89 & \\
\hline precaution from NSI may & Disagree & 1 & 2 & 3 & 8 & 4 & 5 & 8 & 5 & 040 \\
\hline reduce the prevalence of NSI & Don’t know & 0 & 0 & 1 & 3 & 8 & 11 & 9 & 6 & .040 \\
\hline among students & M. score & 1.96 & & 1.81 & & 1.78 & & 1.85 & & \\
\hline & Agree & 52 & 98 & 35 & 95 & 72 & 100 & 159 & 98 & \\
\hline Safe handling of the needle may & Disagree & 1 & 2 & 2 & 5 & 0 & 0 & 3 & 2 & .140 \\
\hline reduce the risks of injury & Don’t know & 0 & & & 0 & 0 & 0 & 0 & 0 & \\
\hline & M. score & 1.96 & & 1.89 & & 2 & & 1.96 & & \\
\hline
\end{tabular}


Table 5. Correlation of perception on risk of NSI and universal precaution

\begin{tabular}{|c|c|c|c|c|c|c|c|c|c|}
\hline \multirow{2}{*}{ No } & \multirow{2}{*}{ Items } & \multicolumn{2}{|c|}{ Agree } & \multicolumn{2}{|c|}{ Disagree } & \multicolumn{2}{|c|}{ Don't Know } & \multirow{2}{*}{$\begin{array}{l}\text { Mean } \\
\text { Scores }\end{array}$} & \multirow{2}{*}{$p$} \\
\hline & & $\mathbf{n}$ & $\%$ & $\mathbf{n}$ & $\%$ & $\mathbf{n}$ & $\%$ & & \\
\hline & Positive Attitude & & & & & & & & \\
\hline $1-$ & Every nursing student is prone to get NSI & 133 & 82 & 28 & 17 & 1 & 1 & 1.65 & .004 \\
\hline $2-$ & Increase workload can lead to NSI & 118 & 73 & 33 & 20 & 11 & 7 & 1.52 & .004 \\
\hline $3-$ & Improper handling of the sharp objects can lead to infection & 143 & 88 & 10 & 6 & 9 & 6 & 1.82 & .015 \\
\hline $4-$ & $\begin{array}{l}\text { Although there is risk of infection, confidence and skillfulness can } \\
\text { prevent NSI }\end{array}$ & 119 & 74 & 26 & 16 & 17 & 10 & 1.57 & .002 \\
\hline 5- & $\begin{array}{l}\text { Unavailability of protective equipment can predispose a person to } \\
\text { NSI }\end{array}$ & 112 & 69 & 39 & 24 & 11 & 7 & 1.45 & .622 \\
\hline 6- & Every student should be immunized with Hepatitis B vaccine & 155 & 96 & 2 & 1 & 5 & 3 & 1.94 & .089 \\
\hline 7- & $\begin{array}{l}\text { Health education on universal precaution fromfor NSI may reduce } \\
\text { the prevalence of NSI among students }\end{array}$ & 145 & 89 & 8 & 5 & 9 & 6 & 1.85 & .040 \\
\hline \multirow[t]{2}{*}{8} & Safe handling of the needle may reduce the risks of injury & 159 & 98 & 3 & 2 & 0 & 0 & 1.96 & .140 \\
\hline & Negative Attitudes & & & & & & & & \\
\hline $1-$ & Students infected with HIV should resign from their college & 35 & 22 & 104 & 64 & 23 & 14 & 1.43 & .001 \\
\hline $2-$ & Reporting after the NSI event is not useful & 35 & 22 & 103 & 63 & 24 & 15 & 1.24 & .001 \\
\hline 3- & $\begin{array}{l}\text { Handling needle without wearing glove is easier and safer than } \\
\text { wearing gloves }\end{array}$ & 46 & 29 & 96 & 59 & 20 & 12 & 1.31 & .549 \\
\hline
\end{tabular}

Taking everything into account, this mediation essentially decreased the occurrence of NSIs/SIs and expanded the report rate of such incidences. Students need to practice onsite postpresentation assessment so that the requirement for early mediation can be evaluated. Moreover, any general well-being and disease control technique are required to be incorporated in the nursing curriculum especially on the subject of HBV inoculation program among students before clinical contact with the patients.

\subsection{Knowledge concerning needle stick injury}

A significant percentage of nursing students have poor knowledge about the illnesses transmitted by contaminated sharp objects. A comparative study by Zhang et al. (2008) on nursing students in Northern China reported that the students showed a general absence of information on safety guidelines. ${ }^{[26]}$ While on the other hand, a study by Saleem, et al., (2010) conducted on more than $85 \%$ of medical students from every class investigated the likelihood of incurring Hepatitis B, Hepatitis C, and HIV from needle stick wounds. ${ }^{[27]}$ It was reported that only $16.4 \%$ third year medical students; $29.5 \%$ fourth year medical students; and $36.2 \%$ graduating medical students were aware of the full impact of NSI and related conventions. Educational modules ought to be referred to as critical sources of data with respect to needle stick wounds and pathogen transmission.

In a study by Norsayani and Noor Hassim (2003), it was discovered that a large portion of the students (98.3\%) obtained information about blood borne illness for the most part from lectures and seminars; $90.8 \%$ from books; and other casual sources at $81.6 \%{ }^{[28]}$ In this context, Rampal et al. (2010) evaluated the prevention of needle stick accidents by adopting correct behaviors on the secured use of needle devices. According to the authors, $74 \%$ of needle stick accidents were caused by incorrect behavior of the healthcare workers and $26 \%$ of accidents related to sharp objects could have been prevented by using secured needles. ${ }^{[29]}$

Similarly, Souza-Borges et al. (2014) identified that 26.2\% and $14 \%$ of those cases were due to mismanagement by healthcare workers and the $73.8 \%$ and $50.9 \%$, respectively were avoidable if trainings to undergraduate nursing students have been provided. ${ }^{[30]}$ The high prevalence of accidents by sharp objects, especially those involving injection needles, phlebotomy, infusion and scalpels could be prevented by adopting safe work practices and use of personal protective equipment. The introduction of devices with safety features could lead to a significantly reduced number of needle stick injuries.

\subsection{Perception of students on needle stick injury}

In this study most of the students had positive perception toward needle stick injuries. Most respondents agree that every student is prone to risk of needle stick injury, but these can be prevented by following universal precautionary measures. At the same line of study by Lal et al. (2006) which showed that majority of the interns (68.3\%) perceived themselves to 
be at a very high risk of acquiring HIV infection during their medical career. ${ }^{[31]}$ Swe et al. (2014) conducted an in-depth focused group discussion which presented students having positive perception of needle stick injury and universal precautionary measures. ${ }^{[32]}$ However, their awareness need to be further enhanced through wider educational promotions on universal precautionary measures and NSIs.

Guglielmi et al. (2005) accentuated that any healthcare worker who is in contact with needles or any sharp instrument faces immense risks of contamination and blood borne infections. Hence, the authors depicted that $38 \%$ of percutaneous complications occur during use; and $42 \%$ before discarding the instrument. ${ }^{[33]}$ The most effective means of preventing the transmission of blood borne pathogens is to avoid the maximum use of needles, using instruments with precautionary and safety measures, and staff training. In ensuring safe practices on the management of needles and other sharp objects, the most important preventive measures to be carried out are utilization of gloves, selection of techniques, and compliance to professional safety measures while using needles and disposing them.

According to Rampal et al. (2010), the risk of contamination is related to the characteristics of the instrument. Most puncture injuries are related to malpractice while re-encapsulating the needles; transferring body fluid to another vessel (e.g., transfer blood from a syringe to a tube); and, improper removal of sharp instruments from a suitable container. ${ }^{[28]}$ Phipps et al. (2002) specified that obviously, needles or other sharp instruments in the nursing workplace can lead to injury especially when the workers are under-trained and lack the expertise in using the instruments with professional accuracy. ${ }^{[34]}$

On other hand, the results of this study revealed that the negative attitude of the nursing students in opining that reporting after NSI was not useful, reflect a lack of understanding of the dangers of non-reporting and possible spread of infection. In a study by Hanafi et al. (2011), it recognized that the normal explanation behind unreported NSIs warranted consideration since there is minimal advantage, particularly when reporting can bring about employment problems or other adverse issues. ${ }^{[35]}$

Obstructions to reporting ought to be suitably distinguished

\section{REFERENCES}

[1] Leliopoulou C, Waterman H, Chakrabarty S. Nurses failure to appreciate the risks of infection due to needle stick accidents: a hospital based survey. J Hosp Infect. 1999 May; 42(1): 53-9. PMid:10363211 and disposed of with a specific end goal to guaranteeing guidance and education of students after presentation. A study by Souza-Borges et al. (2014) reported that few students believed that wearing gloves was of no advantage, as the needle would infiltrate the glove. ${ }^{[29]}$ In Benchmarking study of percutaneous wounds injuries among Saudi healthcare workers without utilizing safety gadgets was $86.8 \%$ compared with United States clinic specialists at $55.7 \%$ as explored by Memish et al. (2015). ${ }^{[36]}$

Taking everything into account, this study discovered high frequencies of exposures among the surveyed students; insufficient practices in prevention and incidence reporting; thereby leading to an increased requirement for introducing standard safety measures among nursing students in anticipation of possible NSI exposures.

\section{CONCLUSION AND RECOMMENDATION}

The incidence of needle stick injuries among the nursing students was much higher in comparison with previous medical research reports, given that nursing students were also at risk of getting infection. Their knowledge concerning universal precaution and hepatitis immunization requires further health education reinforcements. Teaching about standard procedures for universal precaution against needle stick injuries should be included in the undergraduate nursing curriculum. Proper steps are needed to promote the awareness of nursing students about the dangers and prevention of injuries. Most of the students had positive perception toward needle stick injuries as revealed in this study. Hence, it must be ensured that the nursing students are properly educated to recognize the severity of such incidences and thus be trained in the prevention of accidental exposures in their various nursing activities. Training must be incorporated into the curriculum and workplace, on a regular basis, especially when there are innovations and changes made on the sharp instruments. All workers must be informed of the risk of infection transmission through the blood and other biological fluids in the clinical units. Workers must also be aware of the different preventive measures such as the monitoring of standard precautions, use of protective equipments, and the promotion of technically safe conditions.

\section{CONFlicts OF InTEREST Disclosure}

The authors declare that there is no conflict of interest. https://doi.org/10.1053/jhin.1998.0524

[2] Angadi N, Davalgi S, Vanitha SS. Needle stick injuries and awareness towards post exposure prophylaxis for HIV among private general practitioners of Davangere city. Int J Community Med Public Health. 
2016 Jan; 3(1): 335-339. https ://doi .org/10.18203/2394-6 040.ijcmph20151587

[3] Angrup A, Kamlesh T, Chand JS, et al. Needlestick injuries among nurses in a tertiary care hospital: A work hazard or lack of awareness? Asian Journal of Medical Sciences. 2013; 5(1): 58-62. https://doi.org/10.3126/ajms.v5i1.4971

[4] Papastergiou V, Lombardi R, MacDonald D, et al. Global epidemiology of Hepatitis B Virus (HBV) infection. Curr Hepatology Rep. 2015; 14: 171-178. https://doi.org/10.1007/s11901-015-0 269-3

[5] Hassan ZM, Wahsheh MA. Occupational exposure to sharp injuries among Jordanian health care workers. Infectious Diseases in Clinical Practice. 2009; 17(3): 169-174. https://doi.org/10.1097/IPC Ob013e31819b8d10

[6] Khraisat FS, Juni MH, Said SM, et al. Needle stick injuries prevalence among nurses in Jordanian hospitals. International Journal of Public Health and Clinical Sciences. 2015; 2(4): 7-16

[7] Gabriel J. Reducing needlestick and sharps injuries among healthcare workers. Nursing Standard. 2009; 23(22): 41-44. PMid:19263961 https://doi.org/10.7748/ns2009.02.23.22.41.c6777

[8] Khader Y, Burgan S, Amarin Z. Self-reported needle-stick injuries among dentists in north Jordan. Eastern Mediterranean Health Journal. 2009; 15(1): 185-189. PMid: 19469442

[9] Jahangiri M, Rostamabadi A, Hoboubi N, et al. Needle stick injuries and their related safety measures among nurses in a university hospital, Shiraz, Iran. Safety and Health at Work. 2016; 7: 72-77. PMid:27014494 https://doi.org/10.1016/j. shaw . 2015.07 .006

[10] Dement JM, Epling C, Ostbye T, et al. Blood and body fluid exposure risks among health care workers: results from the Duke Health and Safety Surveillance System. Am J Ind Med. 2004 Dec; 46(6): 637-48. PMid:15551378 https://doi.org/10.1002/ajim. 20106

[11] Galazzi A, Rancati S, Milos R. A survey of accidents during the clinical rotation of students in a nursing degree program. G Ital Med Lav Ergon. Jan-Mar 2014; 36(1): 25-31. PMid:24665625

[12] Cheung K, Ching SS, Chang KK, et al. Prevalence of and risk factors for needlestick and sharps injuries among nursing students in Hong Kong. Am J Infect Control. 2012 Dec; 40(10): 997-1001. PMid:22633132 https://doi.org/10.1016/j.ajic. 2012.01 .023

[13] Schmid K, Schwager C, Drexler H. Needlestick injuries and other occupational exposures to body fluids amongst employees and medical students of a German university: incidence and follow-up. J Hosp Infect. 2007 Feb; 65(2): 124-30. PMid:17174445 https: //doi.org/10.1016/j.jhin.2006.10.002

[14] Yang YH, Liou SH, Chen CJ, et al. The effectiveness of a training program on reducing needlestick injuries/sharp object injuries among soon graduate vocational nursing school students in southern Taiwan. J Occup Health. 2007 Sep; 49(5): 424-9. PMid:17951977 https://doi.org/10.1539/joh.49.424

[15] Al-Rawajfah OM, Tubaishat A. Nursing students' knowledge and practices of standard precautions: A Jordanian web-based survey. Nurse Education Today. 2015; 35: 1175-1180. PMid:26043655 https://doi.org/10.1016/j.nedt.2015.05.011

[16] Small L, Pretorius L, Walters A, et al. A surveillance of needle-stick injuries amongst student nurses at the University of Namibia. Health SA Gesondheid. 2011; 16(1).

[17] Hambridge K. Needlestick and sharps injuries in the nursing student population. Nursing Standard. 2011; 25(27): 38-45. PMid:21473346 https://doi.org/10.7748/ns2011.03.25.27.38.c8389

[18] Darawad MW, Al-Hussami M. Jordanian nursing students' knowledge of, attitudes towards, and compliance with infection con- trol precautions. Nurse Education Today. 2013; 33(6): 580-583. PMid:22789874 https://doi.org/10.1016/j.nedt.2012.06 .009

[19] Omer AA, Abdo NM, Salama MF, et al. Occupational injuries prone to infectious risks amongst healthcare personnel in Kuwait: a retrospective study. Med. Princ. Pract. 2015; 24: 123-128. PMid:25531906 https://doi.org/10.1159/000369462

[20] Salmanzadeh S, Rahimi Z, Goshtasbipour M, et al. The prevalence of needle-stick injuries among healthcare workers in Dasht-e-Azadegan, Southern West of Iran. International Journal of Pharmaceutical Research \& Allied Sciences. 2016; 5(2): 417-422.

[21] Askarian M, Malekmakan L. The prevalence of needle stick injuries in medical, dental, nursing and midwifery students at the university teaching hospitals of Shiraz, Iran. Indian Journal of Medical Sciences. 2006; 60(6): 227. PMid:16790948 https://doi.org/10.4103/ 0019-5359.25904

[22] Shiao JSC, Mclaws ML, Huang KY, et al. Student nurses in Taiwan at high risk for needlestick injuries. Annals of Epidemiology. 2002; 12(3): 197-201. https://doi.org/10.1016/S1047-279 7 (01) 00303-9

[23] Tetali S, Choudhury P. Occupational exposure to sharps and splash: Risk among health care providers in three tertiary care hospitals in South India. Indian Journal of Occupational and Environmental Medicine. 2006; 10(1): 35. https ://doi .org/10.4103/0019-5 278.22894

[24] Abozead A, Abuhasheesh M, Nawafleh H, et al. Knowledge and Practices of Jordanian Nurses on Needlestick Injuries: An Evaluative Study. Infectious Diseases in Clinical Practice. 2015; 23(1): 21-25. https://doi.org/10.1097/IPC.0000000000000159

[25] Beynon A. A quality improvement initiative to reduce needlestick injuries. Nursing Standard. 2015; 29(22): 37-42. PMid:25627533 https://doi.org/10.7748/ns.29.22.37.e9471

[26] Zhang Z, Moji K, Cai GX, et al. Risk of sharps exposure among health science students in Northeast China. BioScience Trends. 2008; 2(3): 105-111. PMid:20103912

[27] Saleem T, Khalid U, Ishaque S, et al. Knowledge, attitudes and practices of medical students regarding needle stick injuries. J Pak Med Assoc. 2010 Feb; 60(2): 151-6. PMid:20209710

[28] Norsayani MY, Hassim IN. Study on incidence of needle stick injury and factors associated with this problem among medical students. Journal of Occupational Health. 2003; 45(3): 172-178. https://doi.org/10.1539/joh.45.172

[29] Rampal L, Zakaria R, Sook LW, et al. Needle stick and sharps injuries and factors associated among health care workers in a Malaysian hospital. European Journal of Social Sciences. 2010; 13(3): 354-362.

[30] Souza-Borges FRFD, Ribeiro LA, Oliveira LCMD. Occupational exposures to body fluids and behaviors regarding their prevention and post-exposure among medical and nursing students at a Brazilian public university. Revista do Instituto de Medicina Tropical de São Paul. 2014; 56(2): 157-163. PMid:24626419 https: //doi.org/10.1590/S0036-46652014000200012

[31] Lal P, Meghachandra Singh M, Malhotra R, et al. Perception of risk and potential occupational exposure to HIV/AIDS among medical interns in Delhi. J Commun Dis. 2006; 38(4): 345-9. PMid:17913211

[32] Swe KMM, Somrongthong R, Bhardwaj A. Medical student's perception on incidence of needle sticks injury and preventive measures. J Health Res. 2014; 28(3): 159-64.

[33] Guglielmi G, Andreula C, Muto M, et al. Percutaneous vertebroplasty: indications, contraindications, technique, and complications. Acta radiologica. 2005; 46(3): 256-268. PMid:15981722 https://doi.org/10.1080/02841850510021049 
[34] Phipps W, Honghong W, Min Y, et al. Risk of medical sharps injuries among Chinese nurses. Am J Infect Control. 2002; 30(5): 277-282. PMid:12163861 https://doi.org/10.1067/mic.2002.12243 5

[35] Hanafi M, Mohamed AM, Kassem MS, et al. Needle stick injuries among health care workers of University of Alexandria hospitals. Eastern Mediterranean Health Journal. 2011; 17(1): 26-35.
PMid:21735798

[36] Memish ZA, Assiri AM, Eldalatony MM, et al. Benchmarking of percutaneous injuries at the ministry of health hospitals of Saudi Arabia in comparison with the United States hospitals participating in exposure prevention information network (EPINet ${ }^{\mathrm{TM}}$ ). Int J Occup Environ Med. 2015 Jan; 6(1): 26-33. PMid:25588223 https://doi.org/10.15171/ijoem. 2015.467 